Research article

\title{
CHARACTERISTIC BAND PATTERN IN WESTERN BLOTS FOR SPECIFIC DETECTION OF ANTI-TRICHINELLA SPIRALIS ANTIBODIES IN DIFFERENT HOST SPECIES
}

\author{
ILIĆ Nataša $a^{*}$, GRUDEN-MOVSESIJAN Alisa ${ }^{1}$, ŽIVOJINOVIĆ Milena², \\ SOFRONIĆ-MILOSAVLJEVIĆ Ljiljana ${ }^{1}$ \\ ${ }^{1}$ National Reference Laboratory for Trichinellosis, Institute for the Application of Nuclear Energy - \\ INEP, University of Belgrade, Belgrade, Serbia; ${ }^{2}$ Veterinary Specialist Institute, Požarevac, Serbia
}

(Received 30 December 2013; Accepted 07 February 2014)

\begin{abstract}
Western blot $(\mathrm{Wb})$ is considered to be the gold standard test for Trichinella infection serology, since this method allows specific Trichinella antigens to be distinguished from cross-reactive antigens. This is not the case with widely used antibody assay techniques - indirect immunofluorescence and ELISA - which are sensitive, but subject to crossreactions that make the interpretation of weakly positive results difficult. Application of Trichinella spiralis muscle larvae excretory-secretory (ES) antigens for the specific antibody detection in ELISA resulted in improved specificity compared to that of crude worm extract that was previously in use, but since production of ES has not yet been standardized, differences among laboratories occur. For this reason, the Wb profile of serum samples from different T. spiralis infected host species: human, horse, swine and dog, was investigated in the Serbian National Reference Laboratory for Trichinellosis (NRLT). The common feature of the obtained Wb profiles was the appearance of a triad of bands with molecular masses (Mw) of 45, 49, and $53 \mathrm{kDa}$. The very same triad was recognized by a monoclonal antibody (mAb) 7C2C5 specific for an immunodominant epitope unique to the muscle larvae stage of all species in the genus Trichinella. Inhibition studies confirmed that $\mathrm{mAb}$ and anti-Trichinella antibodies from sera competed for the same parasite epitope. Based on the obtained results, the NRLT introduced the recognition of the above mention triad as the basis for specific anti-Trichinella antibodies detection in the sera of infected hosts.
\end{abstract}

Key words: band triad, anti-Trichinella antibodies, trichinellosis, Western blot

\section{INTRODUCTION}

Nematodes of the genus Trichinella are zoonotic parasites with a cosmopolitan distribution. Infection in domestic and wild animals does not result in disease while in humans it induces trichinellosis. The severity of trichinellosis in humans can range from subclinical to fatal, and the estimated worldwide number of cases is over 2,500 people annually [1]. Infection initiates a strong humoral immune response both in humans and animals that can be recognized by specific antibody detection in the sera or body fluids

\footnotetext{
*Corresponding author: e-mail: natasa@inep.co.rs
} 
[2-4].

In Serbia, 2430 cases of trichinellosis (current data of NRLT) occurred as of the beginning of this century (2001-2012). The number of infected people varied over the years, with a significant reduction of human infections being observed in between 2006 and 2010 (692 cases), as compared to the period 2001-2005 (1565 cases). The prevalence of Trichinella infection in pigs (the main source of infected meat in human infections in Serbia) was $0.11 \%$ in the period 2001-2005, with a two-fold decrease between 2006 and $2008(0.05 \%)$, and reaching the level of only $0.02 \%$ in 2010 (5). The only reported Trichinella species isolated from domestic swine was Trichinella spiralis (T. spiralis) [5-8], while T. spiralis and Trichinella britovi were found in wildlife [5,9,10].

As reported by Cuperlovic et al. [7,11], trichinellosis is the most serious foodborne parasitic disease in Serbia. Transmission occurs in both the sylvatic and domestic cycle. While domestic pigs and synanthropic rats represent the most important hosts in maintaining the transmission cycle, other hosts such as dogs and horses can also be involved [12].

Although serological methods for the detection of Trichinella infection are not considered suitable for meat inspection, they are important for the surveillance of the infection and epidemiological investigations in animal populations, particularly in the areas where prevalence is high [13]. Serological methods are also useful for the presumptive or retrospective diagnosis and surveillance of human infection [14-16]. However, conventional serodiagnostic methods, such as the immunofluorescence antibody assay (IFA) and the enzyme-linked immunosorbent assay (ELISA), can yield results that vary due to antigen quality and may differ in the level of sensitivity. To overcome problems with contradictory or equivocal results, many laboratories use Western blot (Wb) as a confirmatory test. The purpose of this work was to define a Western blot profile characteristic for infection with T. spiralis in humans and other host species important in the epidemiology of Trichinella infection in Serbia.

\section{MATERIALS AND METHODS}

\section{Parasites and antigens}

T. spiralis infective muscle larvae (L1, ISS 161) were recovered from infected Wistar rats by artificial digestion [17]. ES products were obtained by cultivation of muscle larvae (5.000 T. spiralis L1 larvae/ml in DMEM media supplemented with $10 \mathrm{mM}$ Hepes, $2 \mathrm{mM}$ L-glutamine, $1 \mathrm{mM} \mathrm{Na}$-pyruvate and peni/strep $50 \mathrm{U} / \mathrm{ml}$ ) for $18-20 \mathrm{~h}$ at $37^{\circ} \mathrm{C}$ and with $10 \% \mathrm{CO}_{2}$. Culture fluid was harvested, filtered through a $0.2 \mu \mathrm{m}$ filter, concentrated and stored at $-20^{\circ} \mathrm{C}$ until use.

\section{C2C5 monoclonal antibody}

Hybridoma cell line 7C2C5, generously supplied by HR Gamble, was maintained, cloned at NRLT and used for 7C2C5 monoclonal antibody (mAb) production. This $\mathrm{mAb}$ recognizes a unique immunodominant epitope characteristic for the muscle larvae of Trichinella genus and present in a triad of proteins with $\mathrm{Mw}$ of 45,49 and $53 \mathrm{kDa}$ 
[18]. It was regularly used (in 1: 2000) as positive control in Wb analyses.

\section{Serum samples}

Human sera - Sera collected from patients with well-established clinical disease were obtained from a bank of T. spiralis positive human sera maintained at INEP. All sera were positive by IFA with different anti-Trichinella antibody titers. A pool of serum samples from 50 human blood donors was used as the negative control.

Horse sera - Reference serum samples (kindly supplied by E. Pozio, International Trichinella Reference Centre, Rome, Italy) included four samples from Trichinella-free horses (parasitologically and serologically negative), one sample from a Trichinella-free horse (parasitologically negative and serologically false positive), two samples from experimentally infected horses (sera collected 4 and 17 weeks post infection, p.i.) and one sample from a Trichinella-positive horse imported to Italy from Eastern Europe (parasitologically positive and serologically negative).

Swine sera - Serum samples were collected from experimentally inoculated pigs at different stages of infection (9 pigs, 500 T. spiralis L1/pig, 12 weeks infection duration). A pool of 50 sera collected from Trichinella-free pigs was used as a negative control. Additional sera were collected from 17 pigs that were parasitologically confirmed to be infected with T.spiralis, from a group of 726 examined pigs. These naturally infected pigs originated from small private farms in the vicinity of the town of Pozarevac (administrative centre of the T. spiralis endemic District of Braničevo, Serbia).

Dog sera - Serum samples were collected from three experimentally infected dogs (3000 L1/dog, 12 weeks infection duration) and from ten Trichinella-free dogs (all kindly supplied by M Djordjevic, ITHM, Belgrade, Serbia). Additional dog sera were collected from 30 stray dogs that originated from the field (Trichinella endemic district of Braničevo, Serbia, kindly supplied by M Živojinović, Veterinary Specialist Institute, Požarevac, Serbia). In 11 dogs, the presence of specific antibodies was detected by ELISA.

\section{Polyacrylamide gel electrophoresis and Western blot}

ES products were resolved by SDS-polyacrylamide gradient (5-20\%) gel electrophoresis under reducing conditions and then subjected to Western blot on a PVDF membrane. Following transfer, membranes were blocked with TBS $(50 \mathrm{mM}$ Tris- $\mathrm{HCl}, 150 \mathrm{mM}$ $\mathrm{NaCl}) \mathrm{pH} 7.6 / 1 \% \mathrm{BSA}$ and thereafter incubated for $48 \mathrm{hr}$ with serum samples from humans and animal species (diluted 1:50). The 7C2C5 mAb was used as the positive control, while a pool of Trichinella free human or animal sera was applied as the negative control. Inhibition of specific 7C2C5 binding was performed by pre-incubation of blots with undiluted sera from an experimentally infected horse (generously supplied by F. van Knapen). After this and all subsequent steps, membranes were washed with TBS. Secondary antibodies (INEP, Belgrade, Serbia), including anti-human IgG, anti-horse IgG, anti-mouse IgG and anti-swine IgG were all labelled with HRP and used in 1:1000 dilution, while protein A-HRP was in dilution of 1:3000 and used to detect reactive IgG in dog serum samples. Blots were incubated with secondary reagents for 2 hours. Bands 
were visualized with $0.05 \%$ solution of diaminobensidine (DAB, $0.01 \% \mathrm{H} 2 \mathrm{O} 2$ in $0.2 \mathrm{M}$ Tris- $\mathrm{HCl} \mathrm{pH}$ 7.6).

\section{RESULTS}

Interaction of monoclonal antibody $7 \mathrm{C} 2 \mathrm{C} 5$ with $\mathrm{ES}$ products in $\mathrm{Wb}$ resulted in the appearance of a specific band triad at 45, 49 and $53 \mathrm{kDa}$. Since this MoAb recognizes a Trichinella-specific epitope, the occurrence of this triad may indicate the presence of anti-Trichinella antibodies in the examined sera. The reactivity of human serum samples with T. spiralis ES antigens showed, among other bands, the presence of the above triad (Mw 45, 49, $53 \mathrm{kDa}$ ) (Fig.1). These sera were considered positive for anti-T. spiralis IgG. The specific triad was absent in Trichinella-negative sera.

Western blots with horse serum samples indicated the presence of the anti-Trichinella IgG triad only in sera from an artificially infected horse (Fig.2 Lines 3 and 8). Sera from Trichinella free horses (previously confirmed to be serologically negative in both ELISA with ES or tyvelose-BSA antigen, and by IFA, in Rome and Belgrade respectively) did not exhibit the band triad (Fig.2 Lines 4, 5, 6 and 7). Serum sample obtained from a Trichinella free horse that was false positive in ELISA and IFA did not produce the characteristic band triad in Wb (Fig.2 Line 2). A false negative serum sample taken from a naturally infected horse with no specific antibodies detected by ELISA and IFA also appeared negative in Wb (Fig.2 Line 9).

Sera from experimentally infected pigs did not produce the characteristic band triad at Day 0. The characteristic band pattern was present at day 21 p.i., and persisted until day 85 p.i (end of the experiment) (Fig. 3). Results were consistent with those previously obtained by ELISA with ES antigen (data not shown).

Sera from naturally infected pigs gave positive reactions in $\mathrm{Wb}$ (Fig. 4). Sera from these pigs, parasitologically confirmed positive for $T$. spiralis, were also positive for antiTrichinella IgG in ELISA using ES antigen.

Trichinella-specific bands also appeared when sera from artificially and naturally infected dogs were analyzed in Wb (Fig. 5). In only one of the $11 \mathrm{dog}$ sera did the results obtained by ELISA (using ES antigens) differ from the Wb i.e. ELISA was negative while $\mathrm{Wb}$ was positive.

The 45, 49 and $53 \mathrm{kDa}$ band triad was not seen in $\mathrm{Wb}$ analyses with Trichinella negative control sera of human and animal origin, indicating no false positive result.

Reactivity of undiluted sera from Trichinella infected humans [20] and from each animal strain (ten randomly selected ELISA positive sera from pigs or dogs, and one ELISA positive sera from an experimentally infected horse) completely inhibited binding of $\mathrm{mAb} 7 \mathrm{C} 2 \mathrm{C} 5$ to ES antigens as shown in Fig. 6, with a representative serum sample used for inhibition. In this way the specificity of anti- Trichinella antibodies for 45, 49 and 53 $\mathrm{kDa}$ antigen triad was confirmed. 


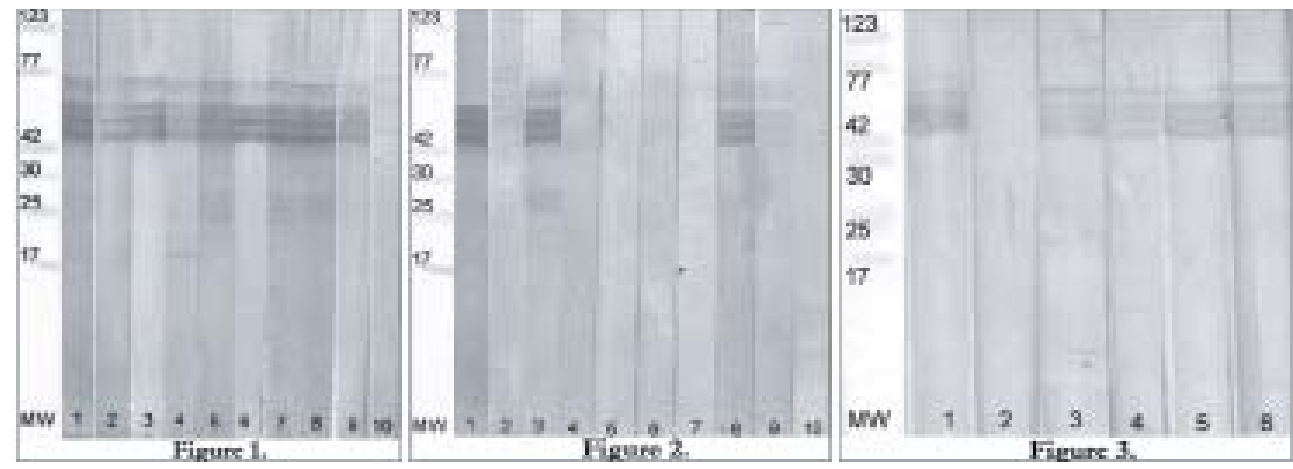

Figure 1. Western blot analyses of serum samples from a T.spiralis infected human. A representative $\mathrm{Wb}$ profile with T.spiralis characteristic band triad pattern in human sera is shown. Line 1. 7C2C5 mAb (MW 45, 49 and $53 \mathrm{kDa}$ ), Lines 2-9. Serum samples from infected people with different anti Trichinella antibody titers: Line 2. titer 1:80, Line 3. titer 1:160, Line 4. titer 1:320, Line 5 and 6. titer 1:640, Line 7 and 8. titer 1:1280, Line 9. titer 1:2560, Line 10. Negative human serum sample (antibody titer $<1: 40$ ). Figure 2 . Western blot analyses with reference horse serum samples (from the International Trichinella Referent Center, Rome, Italy). Line 1. 7C2C5 mAb (MW 45, 49, $53 \mathrm{kDa}$ ), Line 2. Serum sample from a T.spiralis parasitologically negative horse, false positive in IFA and ELISA, Line 3. Serum from a T.spiralis artificially infected horse (4 weeks p.i.), Lines 4-7. Sera from parasitologically negative horses, Line 8. Serum from a T.spiralis artificially infected horse (17 weeks p.i.), Line 9. Serum from a parasitologically positive horse, false negative according to serology, Line 10. Serum from an artificially infected horse (day 0 p.i.), used as a negative control. Figure 3. Western blot analyses of serum samples from pigs experimentally infected with T.spiralis. A representative $\mathrm{Wb}$ profile showing a T.spiralis characteristic band triad pattern is presented. Line 1. 7C2C5 mAb (MW 45,49,53 kDa), Line 2. Pig serum sample, Day 0 of infection, Line 3. Pig serum sample, day 21 p.i., Line 4. Pig serum sample, day 42 of infection, Line 5. Pig serum sample, day 64 of infection, Line 6. Pig serum sample, day 85 of infection.

\section{DISCUSSION}

This study revealed that sera from either human or animal species infected with $T$. spiralis reacted with $T$. spiralis $\mathrm{ES}$ antigens in $\mathrm{Wb}$ and generated the appearance of a characteristic band triad at 45, 49 and $53 \mathrm{kDa}$. These proteins bear an immunodominant epitope shared by all species of the genus Trichinella, which is recognized by the 7C2C5 $\mathrm{mAb}$. The fact that $7 \mathrm{C} 2 \mathrm{C} 5 \mathrm{mAb}$ and antibodies in the sera obtained from $T$. spiralis infected hosts compete for binding to the same epitope, indicates the specificity of polyclonal anti-Trichinella antibodies, and confirms the diagnostic significance of the band triad finding.

All human sera that were considered positive for T. spiralis infection by IFA also bound to the $45,49,53 \mathrm{kDa}$ bands in $\mathrm{Wb}$. However, previous investigations revealed that a number of sera from pregnant women or malignancies [19], as well as from patients with autoantibodies [20,21] and other parasitoses [22-26] gave false positive results in ELISA. When examined in Wb, sera from patients with Trichinella-irrelevant infections or other diseases showed presence of antibodies reactive with T. spiralis ES components of different $\mathrm{Mw}$, some of which belong to the Trichinella-characteristic triad. However, this cross-reactivity never resulted in the appearance of a Trichinella-specific band triad 


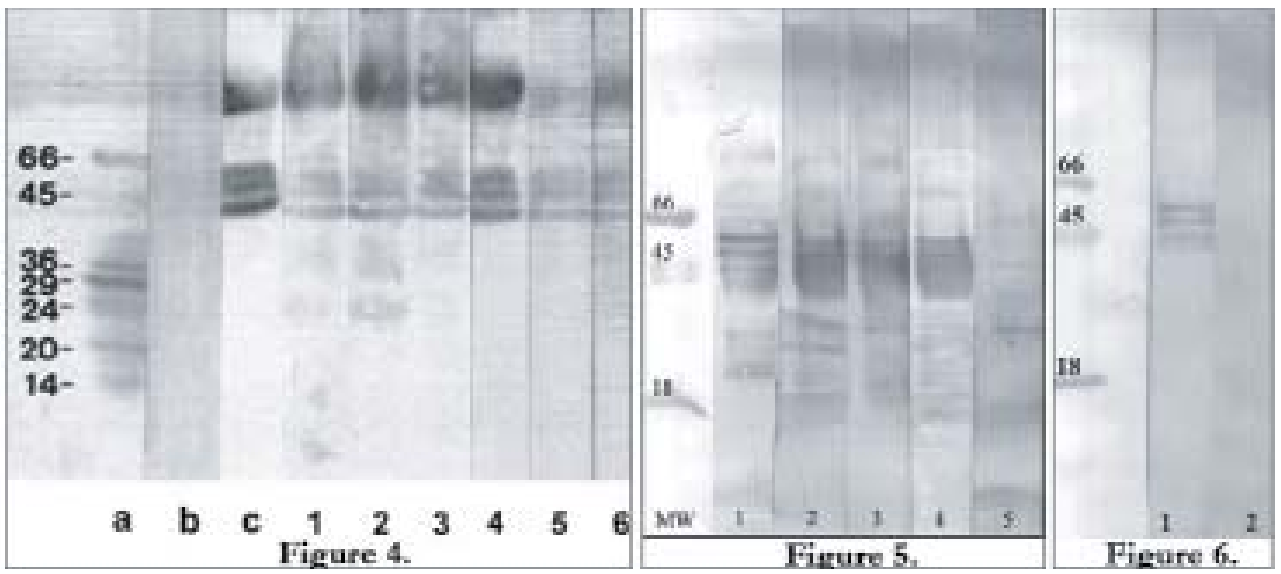

Figure 4. Western blot analyses of serum samples from pigs naturally infected with T.spiralis. Picture shows representative Wb profile with a T.spiralis characteristic band triad pattern in sera of 6 out of 17 infected animals: Line a) MW standards, Line b) Negative pig control serum sample, Line c) 7C2C5 mAb (MW 45, 49 and $53 \mathrm{kDa}$ ), Lines 1-6- serum samples from naturally infected pigs. Figure 5. Western blot analyses of serum samples from dogs experimentally or naturally infected with T.spiralis. Picture shows representative $\mathrm{Wb}$ profile with a T.spiralis characteristic band triad pattern with: Line 1) 7C2C5 monoclonal antibody (Gamble \& Graham, 1984); Line 2) serum of experimentally infected dog; Line 3) and Line 4) serum samples from T.spiralis naturally infected dogs, Line 5) Negative control dog sera pool. Figure 6. Inhibition of 7C2C5 $\mathrm{mAb}$ binding to ES components (representative example). Line 1) 7C2C5; Line 2) Membrane pre-incubated with undiluted sera with polyclonal anti-Trichinella antibodies and subsequently incubated with 7C2C5.

at 45, 49 and $53 \mathrm{kDa}$. Cross-reactivity occurs because of the existence of evolutionary highly conserved epitopes which are common for different pathogens and can also be recognized by some autoantibodies [21]. Sera from healthy blood donors, that tested negative in ELISA for the detection of anti-Trichinella antibodies, were used as negative controls. No false positive results were obtained by $\mathrm{Wb}$ analyses in any of these sera. In our experience, the IFA has proved to be the most reliable method for early detection of anti-Trichinella antibodies in human infections [2,27]. Ivanoska and colleagues [27] demonstrated that the specific antibody could be detected by IFA in $85 \%$ of patient sera collected 20 - 30 days after exposure to Trichinella infection and reaching 100\% by $30-60$, while there was a significant delay of antibody detection by ELISA or CIA (ELISA $47,5 \%$ and CIA $41,7 \%$ or $77,5 \%$ and $87 \%$ for the above-mentioned time intervals, respectively). Other authors [2] have reported that out of the 689 examined patients, antibodies were detected in 210 by IFA but only in 43 by ELISA, indicating a higher sensitivity of IFA compared to ELISA. Based on the results obtained in this study, Wb may also be a valuable tool in the laboratory diagnosis of human infection, especially in cases of doubtful results obtained by other antibody detection methods. Surveillance for Trichinella infection in animals frequently employs serological methods. Widely used serological tests such as ELISA and Wb, as well as less commonly used tests, often give ambiguous results (e.g. in some cases antibodies are detected by only one of several tests) [28-30]. This has been an especially frustrating problem in seroepidemiological studies in horses. In studies conducted with experimentally infected 
horses, results on detection of anti-Trichinella $\operatorname{IgG}$ varied among authors and among the methods used [29,31-33]. Our previous results indicated that specific antibodies could be detected in experimentally infected horses until 32 weeks p.i. by IFA and Wb, but not by ELISA [12,30]. In the present study, sera from experimentally-infected horses, examined by $\mathrm{Wb}$, reacted with components of muscle larvae ES antigens and led to the appearance of a 45,49 and $53 \mathrm{kDa}$ band triad. This finding confirmed positive results obtained by IFA.

Regardless of the problems with the sensitivity of ELISA testing of Trichinella infection in horses, this method is still most commonly used. Although Hill et al. [34] have proved that the persistence of the parasite in horse musculature is similar to that observed in swine and can extend well beyond one year, serological responses to muscle larvae ES antigens in most horses decreased below the cut-off value by 6 month p.i., when measured using a commercially available ELISA. Results obtained in our laboratory showed that an in-house ELISA based on ES antigens failed to detect anti-Trichinella $\mathrm{IgG}$ in sera of experimentally infected horses after 5 months p.i. On the other hand, IFA on paraffin embedded sections of muscle larvae and Wb on ES antigens showed greater sensitivity, since these tests allow detection of anti-Trichinella IgG antibodies for at least 8 months [30].

The results of anti-Trichinella IgG detection in two additional species - swine and dogs - suggested that $\mathrm{Wb}$ was a suitable method for accurate detection of infection in both experimental and naturally infected animals. Wb provided a definitive result even when values obtained by ELISA were close to cut-off values. We can conclude that Wb may be used as a confirmatory test for distinguishing between true positive and false positive sera, yielding unequivocal results.

Scientists from different laboratories are trying to establish a reliable system for detection of Trichinella infection using Wb i.e. different bands have been reported as Trichinella-specific by different authors. For example, Yera et al. [35] claimed T. spiralis antigenic components with Mw of $43-44$ and $64 \mathrm{kDa}$ as discriminative for Trichinella infection. In a study performed by Gomes-Morales and colleagues [36] another threeband pattern, ranging in size from $53-72 \mathrm{kDa}$ (for human sera) and $48-72 \mathrm{kDa}$ (for pig sera) was chosen for it discriminative characteristics. Our laboratory defined a band triad with $\mathrm{Mw}$ of 45,49 and $53 \mathrm{kDa}$ as specific for the detection of anti-Trichinella antibodies. Each laboratory endeavors to define characteristic antigenic components for the serodiagnosis of Trichinella infection according to the known properties of TSL1 group of antigens, and using their own reference materials. Our experience relies on the usage of the 7C2C5 monoclonal antibody specific for the immunodominant epitope characteristic for the genus Trichinella which is present on the above-mentioned band triad, as well as on the application of a large number of reference sera from different species in $\mathrm{Wb}$ analyses. The absence of false positive and false negative results reinforced our belief in the significance of the 45,49 and $53 \mathrm{kDa}$ bands for the detection of Trichinella infection.

In summary, $\mathrm{Wb}$ allows the identification of specific antibodies that recognize components of $T$. spiralis ES antigens and can be a valuable tool for the serological detection of infection in animals and humans. Based on our previous experience and 
the results presented here, all examined host species demonstrate positive reactions by the appearance of a characteristic (triad) banding pattern in the Wb. In accordance to the results presented here, the Serbian NRLT introduced the recognition of the triad of 45, 49 and $53 \mathrm{kDa}$ bands, as the basis for specific anti-Trichinella antibody detection in the sera of infected hosts (as a confirmatory or gold standard test).

\section{ACKNOWLEDGEMENTS}

This work was supported by Ministry of Education, Science and Technological Development, Republic of Serbia, Grant No. 173047.

\section{REFERENCES}

1. Murell KD, Pozio E: Worldwide occurrence and impact of human trichinellosis, 19862009. Emerg Infect Disease 2011, 17:2194-2202.

2. Cuperlovic K, Sofronic-Milosavljevic Lj, Hristovic V: Trichinellosis - immunodiganosis and disease. In: Trichinellosis (G.Ortega-Pierres, H.R.Gamble, F. van Knapen, D. Wakelin, eds.) Centro de Investigacion y Estudios Avanzados IPN, D.F. Mexico, Mexico; 1996, 513-518.

3. Dell A, Haslam SM, Morris HR, Khoo KH: Immunogenic glycoconjugates implicated in parasitic nematode diseases. Biochem Biophys Acta 1999, 1445:353-362.

4. Bruschi F, Chiumiento L: Immunomodulation in Trichinellosis: Does Trichinella Really Escape the Host Immune System? Endocr Metab Immune Disord Drug Targets 2012, 12:4-15.

5. Sofronic-Milosavljevic Lj, Djordjevic M, Plavsic B, Grgic B: Trichinella infection in Serbia in the first decade of the twenty-first century. Vet Parasitol 2013, 194:136-138.

6. Cuperlovic K, Djordjevic M: Trichinella et Trichinellosis. (Turbatovic L, ed.), Institut za higijenu i tehnologiju mesa, Beograd; 2003.

7. Cuperlovic K, Djordjevic M, Pavlovic S: Reemergence of trichinellosis in southeast Europe due to political and economic changes. Vet Parasitol 2005, 132:159-166.

8. Pozio E, Rinaldi L, Marruci G, Musella V, Galati F, Cringoli G, Boireau P, La Rosa G: Host and habitats of Trichinella spiralis and Trichinella britovi in Europe. Int J Parasitol 2009, 39:71-79.

9. Cvetkovic J, Teodorovic V, Marucci G, Vasilev D, Vasilev S, Cirovic D, Sofronic-Milosavljevic Lj: First report on Trichinella britovi in Serbia. Acta Parasitol 2011, 56:232-235.

10. Zivojinovic M, Sofronic-Milosavljevic L, Cvetkovic J, Pozio E, Interisano M, Plavsic B, Radojicic S, Kulisic Z: Trichinella infections in different host species of an endemic district of Serbia. Vet Parasitol 2013, 194:136- 138.

11. Cuperlovic K, Djordjevic M, Pavlovic S, Sofronic Milosavljevic L: Present status of trichinellosis in Yugoslavia: Serbia. Parasite 2001, 8:95-97.

12. Murrell KD, Djordjevic M, Cuperlovic K, Sofronic Lj, Savic M, Djordjevic M, Damjanovic S: Epidemiology of Trichinella infection in the horse: the risk from animal product feeding practices. Vet Parasitol 2004, 123:223-233.

13. Gamble HR, Pozio E, Bruschi F, Nockler K, Kapel CMO, Gajadhar AA: International 
Commission on Trichinellosis: recommendations on the use of serological tests for the detection of Trichinella infection in animals and man. Parasite 2004, 11:3-13

14. Gamble HR: Detection of trichinellosis in pigs by artificial digestion and enzyme immunoassay. J Food Protect 1996, 59:295-298.

15. Noeckler K, Pozio E, Voigt WP, Heidrich J: Detection of Trichinella infection in food animals. Vet Parasitol 2000, 93:335-350.

16. Gottstein B, Pozio E, Nockler K: Epidemiology, Diagnosis, Treatment, and Control of Trichinellosis. Clin Microbiol Rev 2009, 22:127-145.

17. Gamble HR, Bessonov AS, Cuperlovic K, Gajadhar AA, Van Knapen F, Noeckler K, Schenone $\mathrm{H}$, Zhu X: International commission on trichinellosis: recommendations on methods for control of Trichinella in domestic and wild animals intended for human consumption. Vet Parasitol 2000, 93:393-408.

18. Gamble HR, Graham CE: Monoclonal antibody-purified antigen for the immunodiagnosis of trichinosis. Am Vet Med Res 1984, 45:67-74.

19. Sofronic-Milosavljevic Lj, Cuperlovic K, Cokic Z: Tumor originated antibodies from tumor patients recognize Trichinella spiralis antigens. In: Trichinellosis (G.Ortega-Pierres, H.R.Gamble, F. van Knapen, D. Wakelin, eds.) Centro de Investigacion y Estudios Avanzados IPN, D.F. Mexico, Mexico; 1996, 233-238.

20. Robert F, Weil B, Kassis N, Dupouy-Camet J: Investigation of immunofluorescence crossreactions against Trichinella spiralis by Western blot (immunoblot) analysis. Clin Diagn Lab Immunol 1996, 5:575-577.

21. Radovic I, Gruden-Movsesijan A, Ilic N, Mostarica-Stojkovic M, Sofronic-Milosavljevic Lj: Trichinella spiralis shares epitopes with human autoantigens. Mem Instit Oswaldo Cruz 2012, 107:503-509.

22. Linder E, Thors C, Lundin L, Ljungström I, Farah S, Hagi H, Dias F: Schistosome antigen gp50 is responsible for serological cross-reactivity with Trichinella spiralis. J Parasitol 1992, 78:999-1005.

23. De la Rosa JL, Alcantara P, Correa D: Investigation of cross-reactions against Trichinella spiralis antigens by enzyme-linked immunosorbent assay and enzyme-linked immunoelectrotransfer blot assay in patients with various diseases. Clin Diagn Lab Immunol 1995, 2:122-4.

24. Intapan PM, Maleewong W, Sukeepaisarnjaroen W, Morakote N: Potential use of Trichinella spiralis antigen for serodiagnosis of human capillariasis philippinensis by immunoblot analysis. Parasitol Res 2006, 98:227-231.

25. Robinson M, Gustrad TR, Erickson MR: Immunological interactions between Trichinella spiralis and Heligmosomoides polygyrus: cross reactivity between muscle larvae and antibodies raised to unrelated antigens. Int J Parasitol 1997, 27:865-872.

26. Møller LN, Krause TG, Koch A, Melbye M, Kapel CM, Petersen E: Human antibody recognition of Anisakidae and Trichinella spp. in Greenland. Clin Microbiol Infec 2007, 13:702-708.

27. Ivanoska D, Cuperlovic K, Gamble HR, Murrell KD: Comparative efficacy of antigen and antibody detection tests for human trichinellosis. J Parasitol 1989, 75:38-41.

28. Constantino SN, Malmassari SL, Dalla Fontana ML, Diamante MA, Venturiello SM: Diagnosis of human trichinellosis: pitfalls in the use of a unique immunoserological 
technique. Parasite 2001, 8:144-146.

29. Pozio E, Sofronic-Milosavljevic Lj, Gomez Morales MA, Boireau P, Nockler K: Evaluation of ELISA and western blot analysis using three antigens to detect anti-Trichinella IgG in horses. Vet Parasitol 2002, 108:163-178.

30. Sofronic-Milosavljevic Lj, Ilic N, Djordjevic M, Savic M, Gruden-Movsesijan A, Cuperlovic K, Murell KD: Anti-Trichinella antibodies detected in chronically infected horses by IFA and Western blot, but not by ELISA. Vet Parasitol Supp 2005, 132:10711.

31. Soule C, Dupouy-Camet J, Georges P, Ancelle T, Gillet JP, Vaissaire J, Delvigne A, Plareau E: Experimental trichinellosis in horse: Biological and parasitological evaluation. Vet Parasitol 1989, 31:19-36.

32. Yepez-Mulia L, Arriaga C, Viveros N, Adame A, Benitez E, Ortega-Pierres MG: Detection of Trichinella infection in slaughter horses by ELISA and western blot analysis. Vet Parasitol 1999, 81:57-68.

33. Boireau P, Valle I, Roman T, Perret C, Mingyuan L, Gamble HR, Gajadhar A: Trichinella in horses: a low frequency infection with high human risk. Vet Parasitol 2000, 93:309-320.

34. Hill DE, Forbes L, Kramer M, Gajadhar A, Gamble HR:. Larval viability and serological response in horses with long-term Trichinella spiralis infection. Vet Parasitol 2007, 146:107116.

35. Yera H, Andiva S, Perret C, Limonne D, Boireau P, Dupouy-Camet J: Development and evaluation of a western blot kit for diagnosis of human trichinellosis. Clin Diagn Lab Immunol 2003, 10:793-796.

36. Gomez-Morales MA, Ludovisi A, Amati M, Blaga R, Zivojinovic M, Ribicich M, Pozio E: A distinctive Western blot pattern to recognize Trichinella infections in humans and pigs. Int J Parasitol 2012, 42:1017-1023.

\title{
OBRAZAC TRAKA U WESTERN BLOT ANALIZI KARAKTERISTIČAN ZA DETEKCIJU SPECIFIČNIH ANTI-TRICHINELLA SPIRALIS ANTITELA KOD RAZLIČITIH VRSTA DOMAĆINA
}

\author{
ILIĆ Nataša, GRUDEN-MOVSESIJAN Alisa, ŽIVOJINOVIĆ Milena, SOFRONIĆ- \\ MILOSAVLJEVIĆ Ljiljana
}

Western blot (Wb) metoda se smatra zlatnim standardom u serološkoj dijagnostici trihineloze obzirom da ova metoda omogućava razlikovanje specifičnih Trichinella antigena od onih koji daju ukrštenu reakciju. Ovo nije slučaj sa drugim, u praksi češće korišćenim tehnikama baziranim na detekciji antitela - indirektna imunofluorescencija i ELISA, koje su senzitivne ali podložne unakrsnoj reaktivnosti što otežava interpretaciju slabo pozitivnih rezultata. Primena ekskretorno-sekretornog (ES) antigena larvi u mišićima, Trichinella spiralis u detekciji specifičnih antitela u ELISA testu, rezultirala je povećanom specifičnošću testa u odnosu na prethodni koji je bio baziran na primeni totalnog solubilnog ekstrakta parazita. Ipak, obzirom da proizvodnja ES antigena još 
uvek nije standardizovana, postoje izvesne razlike između rezultata dobijenih u različitim laboratorijama. Iz ovog razloga, u Nacionalnoj Referentnoj Laboratoriji Srbije za Trihinelozu (NRLT) ispitivali smo Wb profil uzoraka seruma različitih vrsta domaćina inficiranih sa T. spiralis, i to ljudi, konja, svinja i pasa. Zajedničko svojstvo dobijenih Wb profila bila je pojava tripleta traka koje odgovaraju proteinima sa molekulskim masama (Mw) od 45, 49, $53 \mathrm{kDa}$. Isti triplet prepoznaju i monoklonska antitela (mAt) 7C2C5 specifična za imunodominantni epitop karakterističan za stadijum mišićnih larvi svih vrsta parazita iz genusa Trichinella. Eksperimentalne studije inhibicije su pokazale da postoji kompeticija između $\mathrm{mAt} i$ anti-Trichinella antitela iz seruma za isti epitop parazita. $\mathrm{Na}$ osnovu dobijenih rezultata, NRLT uvodi prepoznavanje pomenutog tripleta traka kao osnovu za detekciju specifičnih anti-Trichinella antitela u serumima inficiranih domaćina. 